\author{
파쇄 대나무 급여수준이 젓소 거세우의 성장과 도체특성에 \\ 미치는 영향 \\ 안병홍* . 강춘성** . 추교문* . 조희웅* \\ 경상대학교 동물자원과학부*, 들얼농장**
}

\title{
Effects of Different Levels of Crushed Bamboo Chip on Performance and Carcass Characteristics of Holstein Steers
}

\author{
B. H. Ahn*, C. S. Kang**, G. M. Chu* and H. W. Cho*
}

Faculty of Animal Science and Technology, Gyeongsang Natl. University*, Deul Url Dairy Farm**

\section{ABSTRACT}

Twenty eight Holstein steers 12 months old and weighing about 300kg were randomly allotted into one of four groups being fed ammoniated rice straw(ARS) and substituted 30\%, 40\% and 50\% crushed bamboo chip for ARS to determine the effects of different levels of bamboo chip on performance, digestibility and carcass characteristics.

Daily weight gain was reduced as the substitution levels of bamboo chip for ARS as a roughage source increased but there were no differences in daily weight gain between steers fed ARS alone and $30 \%$ bamboo chip for ARS. Concentrates intakes were not different between treatments by the substitution levels of bamboo chip for the whole fattening period. Roughage intake tended to increase as the substitution levels of bamboo chip increased. Total feed intake was not affected by the substitution levels of bamboo chip. However, feed efficiency got worse with increasing levels of bamboo chip. Animals fed the roughage substituting $30 \%$ bamboo chip for ARS were higher in profit by 13\% than animals fed ARS alone as a roughage source.

Digestibilities of Dry matter(DDM) and crude fiber(DCF) were highest in animals fed ARS alone as a roughage source. DDM's were lower in higher substitution levels of crushed bamboo chip but there were no differences in DCF among animals fed different levels of bamboo chip as a roughage source. Crude protein digestibility was not affected by ammoniated rice straw or by the different levels of bamboo chip.

Dressing percentage and backfat thickness were not affected by ammoniated rice straw or by the levels of bamboo chip but ribeye area was narrowed as the levels of bamboo chip increased. Beef color, fat color, texture, maturity and marbling score were not affected by feeding of ammoniated rice straw or by the levels of bamboo chip.

According to these results, it may be concluded that profit can increase when Holstein bulls are castrated and roughage containing ammoniated rice straw plus 30\% bamboo chip is offered.

(Key words : Holstein steer, Bamboo, Performance, Digestibility, Carcass characteristics)

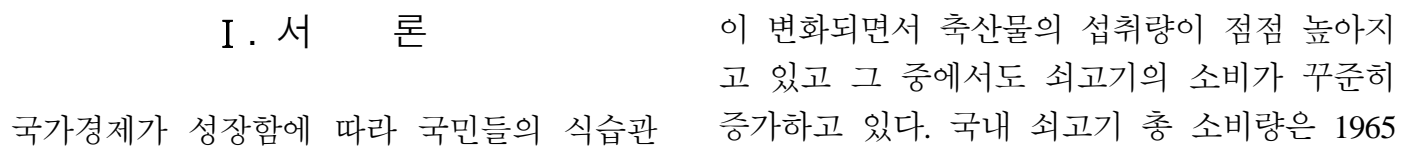

Corresponding author : Byung. H. Ahn, Faculty of Animal Science and Technology, Gyeongsang Natl. University, Jinju, 660-701, Korea.

Tel:055-751-5416, E-mail:bhahn@gsnu.ac.kr 
년에 27.3천 톤에서 2003년에는 402.7천 톤으로 15 배가 증가하였으나 국내생산은 203천 톤으로 쇠고기 자급율이 $50 \%$ 정도에 머므르고 있다.

현재 우리나라에서는 쇠고기 시장의 개방에 대응하기 위하여 도체등급제를 실시하고 있고 이에 따라 가축은 도체등급판정을 받고 판매가 격이 결정되고 있다. 그런데 이전에는 가축의 판매는 가축시장에서 생축을 판매해왔기 때문 에 젖소 수송아지라도 한우 수송아지에 비하여 가격차이가 크게 나지는 않았으나 지금은 가격 이 도체의 육질에 의하여 결정되기 때문에 도 체등급판정시 육질이 떨어지는 경우에는 가격 이 낮을 수밖에 없다. 이제까지의 도체등급판 정결과를 보면 젖소 수소는 거의 전부(97.4\%; 축산물등급판정소, 2003)가 육질 3등급을 받아 서 젖소 수소의 육질은 낮으며 축우비육에서 젖소 수소 비육은 가장 큰 타격을 받을 것으로 예상된다.

그런데 젖소 거세우 비육시에는 2 등급이상을 받으면 수익이 발생하므로(농협, 2000), 젖소 수 송아지도 거세를 하여서 비육을 시키면 2등급 이상을 받을 수 있는 비율이 높아지므로 거세 를 하여서 비육을 하는 것이 유리하다.

소의 조사료원으로는 우리나라에서 생산되고 있는 볏짚을 주로 이용하고 있으나 볏짚 중에 는 조단백질이 낮고(4.5\%) 조섬유(28.3\%)와 조 회분(15.1\%)이 높아 근래에는 볏짚에 암모니아 처리를 하여 급여하고 있다. 볏짚에 암모니아 처리(3\%)를 하면 볏짚중의 조섬유 함량은 큰 변동이 없으나 조단백질이 $11.06 \%$ 로 증가한 다.

섬유소는 식물체의 건물중 $1 / 4$ 에서 $1 / 2$ 을 차 지하고 있는 주 구성성분으로서 세계에서 가장 풍부한 가용자원이다. 섬유소를 반추동물 사료 로 이용하는 것은 식물체의 효과적인 처리수단 인 동시에 양질의 단백질을 생산할 수 있기도 하다. 옛날부터 여러 가지의 섬유소 자원을 반 추동물의 사료로 이용할 수 있는 가능성에 대 하여 조사를 하였는데 이들 중에는 톱밥, 신문 지, wood pulp 및 나무를 화학적으로 분해시킨 것 등이 해당된다(Riquelme 등, 1975).

국내 배합사료 원료의 자급율은 그 동안 계
속 감소되었으며 2004년도에 단미. 보조사료를 12,176천 톤에 24.5억 불 어치를 수입하였고(한 국단미사료협회, 2005), 앞으로도 배합사료의 원 료에 대한 수입원료의 의존도는 증가할 전망이 다. 국제 곡류가격의 상승은 국내 사료업계의 경영을 어렵게 하고 있다. 또한 세계 경제가 단일화되면서 생산원가 면에서 국제경쟁력을 확보하지 못하면 해당 산업의 존립이 위태로운 상황이므로 국내 축산업은 과거 어느 때보다도 사료비 절감의 필요성이 절실하다. 이러한 어 려움을 극복하기 위해서 아직 사료원료로 사용 되지 않고 있으나 대량생산이 가능하며 영양적 인 측면과 경제적인 면에서 사료적 가치가 있 으나 사료로서 이용되지 않고 있는 조사료원을 개발하여 축우의 사료로 이용하는 것이 대단히 중요하다. 대나무는 1999년에는 28,424속(산림 청, 2000)을 생산하였고 거의 대부분(95.3\%)을 경남에서 생산하고 있으며, 잎과 줄기는 사료 로 사용되지 않고 그대로 방치되고 있다.

그러므로 본 연구에서는 부존자원의 사료화 를 위하여 젖소 거세우에게 경남지방에서 다량 생산되고 있는 대나무(잎과 가지포함)를 암모니 아 처리 볏짚에 대하여 수준별로 급여 하였을 때 이 대나무사료가 젖소 거세우의 성장과 육 질에 미치는 영향을 구명하고자 한다.

\section{ㅍ. 재료 및 방법}

\section{Holstein 젖소 거세우를 이용한 비육시험}

\section{1) 공시동물}

체중 $300 \mathrm{~kg}$ 정도 되는 Holstein 젖소 거세우 28두를 공시동물로 사용하였다.

\section{2) 시험설계}

시험구는 조사료원으로서 암모니아 처리 볏 짚 급여구와 대나무(잎과 가지포함) 급여구(30, 40, 50\%)의 4 처리구를 두었고, 공시동물은 한 처리구당 7 두씩 배치하였으며, 체중 $300 \mathrm{~kg}$ 부터 $700 \mathrm{~kg}$ 까지 이들 조사료를 급여하였다. 전 처리 구에 에너지와 단백질이 동일한 농후사료를 급 여하였고, 비육시기별 농후사료의 배합비율과 
Table 1. Ingredients and chemical composition of experimental concentrates(as fed basis)

\begin{tabular}{|c|c|c|c|}
\hline Item & $\begin{array}{c}\text { First } \\
\text { fattening }\end{array}$ & $\begin{array}{c}\text { Mid } \\
\text { fattening }\end{array}$ & Finishing \\
\hline \multicolumn{4}{|c|}{ Ingredients composition(\%) } \\
\hline Yellow corn & 48.80 & 23.60 & 25.00 \\
\hline Wheat & 0.00 & 13.00 & 16.00 \\
\hline Wheat bran & 5.34 & 10.00 & 8.00 \\
\hline Corn gluten feed & 4.00 & 6.00 & 8.00 \\
\hline Tapioca & 8.00 & 8.00 & 7.00 \\
\hline Distillers grain & 6.00 & 3.50 & 0.00 \\
\hline Palm oil mea & 6.50 & 9.00 & 8.00 \\
\hline Coconut meal & 12.00 & 14.00 & 12.00 \\
\hline Molasses & 5.00 & 6.50 & 5.00 \\
\hline Kapok meal & 0.00 & 1.50 & 1.50 \\
\hline Rapeseed meal & 0.00 & 0.00 & 5.00 \\
\hline Limestone & 1.42 & 1.90 & 1.90 \\
\hline Tricalcium phosphate & 0.28 & 0.30 & 0.00 \\
\hline Salt & 0.60 & 0.70 & 0.70 \\
\hline Vitamins* & 0.10 & 0.10 & 1.10 \\
\hline Minerals** & 0.10 & 0.10 & 0.10 \\
\hline Yeast culture & 1.86 & 1.80 & 1.70 \\
\hline Total & 100.00 & 100.00 & 100.00 \\
\hline
\end{tabular}

* Contains 3,800IU of vitamin A, 400IU of vitamin $\mathrm{D}_{3}$, 20IU of vitamin $\mathrm{E}$ per $\mathrm{kg}$ of feed.

** Contains $50 \mathrm{mg}$ of iron, $0.150 \mathrm{mg}$ of cobalt, $7 \mathrm{mg}$ of copper, $24 \mathrm{mg}$ of manganese, $30 \mathrm{mg}$ of zinc, $0.60 \mathrm{mg}$ of iodine, $0.150 \mathrm{mg}$ of selenium per $\mathrm{kg}$ of feed.

Table 2. Chemical composition of bamboo chip and $\mathrm{NH}_{3}$-treated rice straw

\begin{tabular}{lcc}
\hline Item & DM basis & Rice straw $^{2)}$ \\
\hline \hline Dry matter (\%) & 96.15 & 92.28 \\
Moisture (\%) & 3.85 & 7.22 \\
Crude fat (\%) & 2.28 & 2.39 \\
Crude fiber (\%) & 46.70 & 35.01 \\
Crude protein (\%) & 5.19 & 11.00 \\
Crude ash (\%) & 3.51 & 11.21 \\
NFE (\%) & 42.32 & 40.39 \\
NDF (\%) & 78.19 & 69.44 \\
ADF (\%) & 58.13 & 48.41 \\
\hline
\end{tabular}

1) DM bamboo chip.

2) $\mathrm{DM} \mathrm{NH}$-treated rice straw.
Table 3. Mineral composition of bamboo chip

\begin{tabular}{crrr}
\multicolumn{3}{c}{ (as DM basis) } & Unit : ppm \\
\hline Item & $\begin{array}{r}\text { Bamboo } \\
(2001 \text { 년) }\end{array}$ & $\begin{array}{r}\text { Bamboo } \\
(2002 \text { 년) }\end{array}$ & Average \\
\hline \hline $\mathrm{Al}$ & 116.69 & 137.10 & 126.90 \\
$\mathrm{As}$ & 7.33 & 8.80 & 8.07 \\
$\mathrm{Ca}$ & $1,259.64$ & $1,279.84$ & $1,263.94$ \\
$\mathrm{Cr}$ & 3.41 & 3.65 & 3.54 \\
$\mathrm{Cu}$ & 0.24 & 4.67 & 2.46 \\
$\mathrm{Fe}$ & 120.86 & 587.75 & 354.31 \\
$\mathrm{Ge}$ & 19.96 & 28.45 & 24.20 \\
$\mathrm{~K}$ & $3,927.37$ & $4,398.48$ & $4,162.93$ \\
$\mathrm{Mg}$ & 471.22 & 544.64 & 507.94 \\
$\mathrm{Mn}$ & 87.05 & 74.33 & 80.69 \\
$\mathrm{Mo}$ & 1.90 & 17.98 & 9.95 \\
$\mathrm{Na}$ & 143.44 & 192.58 & 168.01 \\
$\mathrm{Ni}$ & 0.00 & 0.15 & 0.07 \\
$\mathrm{P}$ & $1,413.93$ & $1,007.21$ & $1,210.58$ \\
$\mathrm{~Pb}$ & 0.52 & 0.29 & 0.40 \\
$\mathrm{Se}$ & 13.20 & 16.36 & 14.78 \\
$\mathrm{Si}$ & 17.49 & 16.63 & 17.07 \\
$\mathrm{Zn}$ & 20.79 & 32.43 & 26.61 \\
\hline & & & \\
\hline
\end{tabular}

성분은 Table 1 과 같고, 본 연구에 사용된 대나 무의 일반성분과 무기물 함량은 Table 2 및 3 과 같다.

\section{3) 시험기간 및 시험장소}

시험기간은 체중 $300 \mathrm{~kg}$ 부터 $700 \mathrm{~kg}$ 까지 16 개월(480일)간 실시하였는데, 비육전기 150일, 비육중기 160 일 및 비육후기 170 일간 실시하였 다. 본 시험은 경남 사천소재 들얼목장에서 수 행하였다.

\section{4) 사양관리}

공시동물은 생후 6 개월 령에 거세를 실시하 였으며, 처리구별로 나누어 군사(group feeding) 를 시켰고, 사료는 처리구별로 급여하였다. 대 나무는 목재파쇄기(Wood chipper)를 이용하여 대나무를 잎과 가지를 함께 파쇄하여 파쇄물 
(bamboo chip)을 수준별로 암모니아 처리 볏짚 에 혼합하여 젖소 거세우에게 급여하였다. 농 후사료는 체중의 $2.50 \%$ 에서 $1.70 \%$ 범위 내에 서, 조사료는 체중의 $0.50 \%$ 에서 $0.15 \%$ 범위 내 에서 체중이 증가함에 따라 조절하여 급여하였 다. 전 시험기간 동안 조사료와 농후사료는 각 사육시기별로 나누어 체중별로 계량하여 급여 하였다. 각 사육시기별로 계량된 암모니아 처 리 볏짚과 대나무를 먼저 급여하고 다음에 농 후사료를 1 일 2회로 나누어 급여하였다. 사료 섭취량은 일주일 단위로 측정하였고 체중은 1 개월 간격으로 측정하였으며, 물은 자유로이 먹게 하였다.

\section{5) 조사항목}

사양시험에서는 증체량, 사료섭취량, 사료효 율 및 경제성 분석을 실시하였고, 도체등급에 서는 육량등급(도체중, 배최장근 단면적, 등지 방 두께)과 육질등급(근내지방도, 육색, 지방색, 조직감, 성숙도)을 조사하였고, 소화시험에서는 일반성분의 소화율을 구하였다.

\section{6) 조사방법}

체중은 우형기를 이용하여 1 개월 간격으로 측정하여 일일 증체량을 산출하였고, 사료섭취 량은 일주일 간격으로 각 처리구별로 측정하여 급여량에서 잔량을 감하여 산출하였으며, 육량 과 육질등급은 축협중앙회 축산물등급판정소의 소 도체의 판정기준(2001)에 의하여 각 처리구 당 7 두씩 생체중, 육량등급, 육질등급, 육량지 수 및 경락단가를 조사하였다. 경제성 분석에 서 경매가격은 시험 축 도체는 축협 공판장에 상장하여 경매 후 경락가격을 조사하였고 사료 비중에서 농후사료비는 시험기간중 공시동물이 섭취한 사료섭취량에서 사료단가를 곱하여 구 하였다.

\section{7) 통계처리}

본 시험에서 얻은 결과들은 SAS(Strategic Application Software) 통계 package(2000)의 General linear model procedure를 이용하여 분산분석을 하였고, Duncan's multiple range test로 처리하여
평균간의 유의성을 검정하였다.

\section{2. 면양을 이용한 소화시험}

소화율은 전분채취법으로 구하였는데 평균체 중 $60.75 \mathrm{~kg}$ 되는 12 두의 수 면양을 대사틀에 넣어 예비시험기간 7일과 본시험기간 7일 계 14 일 동안 소화시험을 수행하였다. 시험사료는 젓소 거세우 비육시험에서 사용한 것과 동일한 사료를 사용하였고, 사료 급여량은 공시 수면 양의 대사체중을 구하여 하루 유지에 필요한 $\mathrm{ME}(\mathrm{MEm})$ 을 구하고 이 요구량에 $10 \%$ 를 더하여 총 사료급여량으로 하였으며, 총 사료급여량 중 농후사료, 볏짚과 대나무의 급여량은 $7: 2: 1$ 로 하였다. 통계처리는 젖소 거세우 비육시험에서 이용한 방법과 동일한 방법으로 구하였다.

\section{III. 결과 및 고찰}

\section{Holstein 젖소 거세우를 이용한 비육시험}

젖소 수소를 거세를 시키고 암모니아 처리 볏짚을 조사료로 급여하면서 잎과 줄기가 포함 된 대나무의 급여수준을 다르게 하여 암모니아 처리 볏짚을 대체하면서 생후 12 개월령 부터 28 개월령까지 16 개월간 비육을 시켰을 때 젖소 거 세우의 증체량에 미치는 영향을 보면 Table 4에 제시된 바와 같다. 일당증체량은 비육초기에는 $1.03 \sim 1.12 \mathrm{~kg}$ 이었고 조사료로서 대나무를 $50 \%$ 암모니아 처리 볏짚에 대체하여 급여한 구가 일당증체량이 제일 낮았으나 $(\mathrm{p}<0.05)$ 대나무를 $40 \%$ 까지 급여한 구는 암모니아 볏짚 급여구와 비교하여 일당증체량에서 차이가 없었다. 비육 중기에는 $0.70 \sim 0.89 \mathrm{~kg}$ 이었고 조사료로서 암 모니아 처리 볏짚 급여구가 일당 증체량이 제 일 높았고 대나무 급여수준이 증가할수록 일당 증체량이 감소하였으나 암모니아 처리 볏짚 급 여구와 대나무 $30 \%$ 급여구와는 차이가 없었다. 비육말기에는 일당증체량은 $0.58 \sim 0.72 \mathrm{~kg}$ 이었 고 대나무 급여수준이 증가할수록 일당증체량 이 감소하였으나 대나무 $30 \%$ 급여구는 암모니 아 처리 볏짚 급여구와는 차이가 없었다. 전체 
Table 4. Effects of the substitution levels of crushed bamboo chip for ammoniated rice straw on body weight gain of Holstein steers

\begin{tabular}{lcccc}
\hline Item & $0 \%$ & $30 \%$ & $40 \%$ & $50 \%$ \\
\hline \hline Body weight(kg) & & & & \\
Initial & $300.7^{\mathrm{a}} \pm 14.0$ & $301.5^{\mathrm{a}} \pm 14.8$ & $302.3^{\mathrm{a}} \pm 11.6$ & $306.2^{\mathrm{a}} \pm 12.8$ \\
Mid fattening & $465.0^{\mathrm{a}} \pm 30.0$ & $468.5^{\mathrm{a}} \pm 27.8$ & $470.3^{\mathrm{a}} \pm 24.3$ & $460.0^{\mathrm{b}} \pm 23.0$ \\
Finishing & $607.0^{\mathrm{a}} \pm 34.2$ & $602.2^{\mathrm{a}} \pm 35.7$ & $591.2^{\mathrm{b}} \pm 30.6$ & $571.7^{\mathrm{c}} \pm 30.2$ \\
Final & $729.7^{\mathrm{a}} \pm 41.1$ & $720.5^{\mathrm{a}} \pm 40.3$ & $690.4^{\mathrm{b}} \pm 35.8$ & $670.0^{\mathrm{c}} \pm 35.4$ \\
\hline Daily weight gain(kg) & & & & \\
First fattening & $1.10^{\mathrm{a}} \pm 0.04$ & $1.11^{\mathrm{a}} \pm 0.04$ & $1.12^{\mathrm{a}} \pm 0.03$ & $1.03^{\mathrm{b}} \pm 0.03$ \\
Mid fattening & $0.89^{\mathrm{a}} \pm 0.03$ & $0.84^{\mathrm{a}} \pm 0.02$ & $0.76^{\mathrm{b}} \pm 0.03$ & $0.70^{\mathrm{c}} \pm 0.02$ \\
Finishing & $0.72^{\mathrm{a}} \pm 0.03$ & $0.70^{\mathrm{a}} \pm 0.02$ & $0.58^{\mathrm{b}} \pm 0.02$ & $0.58^{\mathrm{b}} \pm 0.02$ \\
Mean & $0.90^{\mathrm{a}} \pm 0.03$ & $0.88^{\mathrm{a}} \pm 0.04$ & $0.82^{\mathrm{b}} \pm 0.03$ & $0.77^{\mathrm{c}} \pm 0.03$ \\
\hline Means \pm SD & & & &
\end{tabular}

0\%: ammoniated rice straw 100\%; 30\%: bamboo chip with stem plus leaves 30\%; 40\%: bamboo chip with stem plus leaves 40\%; 50\%: bamboo chip with stem plus leaves 50\%.

a,b,c Means with different superscripts are significantly different $(\mathrm{P}<0.05)$.

평균 일당증체량에서는 $0.77 \sim 0.90 \mathrm{~kg}$ 이었고 암 모니아 처리 볏짚 급여구가 $0.90 \mathrm{~kg}$ 으로 일당증 체량이 높았으나 대나무 $30 \%$ 급여구와는 차이 가 없었고 대나무 급여구간에는 대나무 급여수 준이 증가할수록 일당증체량은 점차적으로 감 소하였다. 그러므로 젖소 거세우에게 대나무를 조사료로 급여할 경우에는 일당증체량 면에서 는 암모니아 처리 볏짚에 대하여 $30 \%$ 까지는 급여하는 것이 가능 하리라 사료된다.

진 등(2001)은 젖소 거세우를 24개월령까지 비육시 일당증체량은 $0.85 \sim 0.90 \mathrm{~kg}$ 이라고 하였 는데 본 시험에서는 28 개월령까지 비육시 0.77 $\sim 0.90 \mathrm{~kg}$ 으로 일당증체량이 비슷한 범위에 있 었다. 常石 등(1993)은 비육전기에 조사료를 많 이 급여하면 체중이 증가한다고 하였는데 본시 험에서도 비육초기에 대나무를 $40 \%$ 까지 급여 한 구는 암모니아 처리 볏짚 급여구와 비교하 여 일당증체량이 차이가 없었다. 김 등(2002)은 볏짚에 양질의 조사료를 보충하였을 때에는 볏짚 단독 급여구보다 일당증체량과 사료효율이 상당 히 증가되었다고 하였으나, Mader와 Horn(1986) 은 소화가 잘 되는 조사료 대신 저질 조사료를 급여하였을 때에는 일당증체량이 감소한다고 하였다. 본 시험에서도 대나무의 급여수준이 높
아질수록 일당증체량이 상당히 감소하여서 조 섬유 함량이 높은(46.70\%) 대나무를 많이 급여 하면 증체량이 상당히 감소하는 것 같다.

암모니아 처리 볏짚에 대한 대나무 급여수준 이 사료섭취량과 사료효율에 미치는 영향을 보 면 Table 5에 제시된 바와 같이 농후사료섭취 량은 비육초기에는 $8.49 \sim 8.58 \mathrm{~kg}$ 이었고, 비육 중기에는 $8.87 \sim 9.07 \mathrm{~kg}$ 이었으며, 비육후기에는 $9.07 \sim 9.24 \mathrm{~kg}$ 으로 비육전기간에 걸쳐 조사료중 의 대나무 급여수준에 의하여 처리구간에 큰 차이가 없었다. 전체 평균 농후사료섭취량은 $8.81 \sim 8.96 \mathrm{~kg}$ 이었다. 그러나 농후사료섭취량은 조사료중에 대나무 급여수준이 증가할수록 점 차적으로 약간씩 감소하는 경향이었다. 이러한 것은 동물체내에서의 대나무 소화 속도가 늦어 지는데 기인하는 것 같다. 그러나 비육우를 우 사내에서 사육하면서 농후사료를 많이 급여하 면 acidosis가 자주 발생하고 이 acidosis를 감소 시키기 위하여 조사료를 농후사료 다급시에 급 여하고 사료의 변경은 서서히 하여야 한다고 하였다(Gill 등, 1979).

조사료섭취량은 비육초기에는 $1.35 \sim 1.42 \mathrm{~kg}$ 이었고, 비육중기에는 $1.81 \sim 2.36 \mathrm{~kg}$ 이었으며, 비육후기에는 $1.88 \sim 2.22 \mathrm{~kg}$ 이었고 비육전기간 
Table 5. Effects of the substitution levels of crushed bamboo chip for ammoniated rice straw on feed intake and feed efficiency of Holstein steers

\begin{tabular}{|c|c|c|c|c|}
\hline Item & $0 \%$ & $30 \%$ & $40 \%$ & $50 \%$ \\
\hline \multicolumn{5}{|c|}{ Concentrate intake(kg/head/day) } \\
\hline First fattening & 8.58 & 8.50 & 8.52 & 8.49 \\
\hline Mid fattening & 9.07 & 8.91 & 8.98 & 8.87 \\
\hline Finishing & 9.24 & 9.10 & 9.19 & 9.07 \\
\hline Mean & 8.96 & 8.84 & 8.90 & 8.81 \\
\hline \multicolumn{5}{|c|}{ Roughage intake(kg/head/day) } \\
\hline First fattening & 1.35 & 1.40 & 1.40 & 1.42 \\
\hline Mid fattening & 1.81 & 2.12 & 2.17 & 2.36 \\
\hline Finishing & 1.89 & 1.88 & 2.08 & 2.22 \\
\hline Mean & 1.68 & 1.80 & 1.88 & 2.00 \\
\hline \multicolumn{5}{|c|}{ Total feed intake(kg/head/day) } \\
\hline First fattening & 9.93 & 9.90 & 9.92 & 9.91 \\
\hline Mid fattening & 10.88 & 11.03 & 11.15 & 11.23 \\
\hline Finishing & 11.13 & 10.98 & 11.27 & 11.29 \\
\hline Mean & 10.64 & 10.64 & 10.78 & 10.81 \\
\hline \multicolumn{5}{|l|}{ Feed efficiency } \\
\hline First fattening & 9.03 & 8.92 & 8.86 & 9.62 \\
\hline Mid fattening & 12.23 & 13.13 & 14.67 & 16.04 \\
\hline Finishing & 15.46 & 15.69 & 19.43 & 19.47 \\
\hline Mean & 12.24 & 12.58 & 14.32 & 15.04 \\
\hline
\end{tabular}

0\%: ammoniated rice straw 100\%; 30\%: bamboo chip with leaves plus stem 30\%; 40\%: bamboo chip with leaves plus stem 40\%; 50\%: bamboo chip with leaves plus stem $50 \%$.

에는 $1.68 \sim 2.00 \mathrm{~kg}$ 이었으며 조사료로서 대나 무 급여수준이 높아질수록 조사료섭취량도 약 간씩 증가하는 경향이었다. 이러한 경향은 대 나무를 푸른 상태에서 파쇄하여 급여하였기 때 문에 기호성이 약간 높아져서 섭취량이 증가한 것으로 사료된다.

저질 조사료를 급여하면 이들 저질 조사료가 소화기내에서 천천히 소화되기 때문에 많은 량 의 비소화물질이 장내에 남게 되어 사료의 섭 취량이 감소한다. 따라서 cellulose 함량이 높은
조사료는 그 섭취량이 줄어들게 된다고 하였다 (Van Soest, 1965a; Balch와 Campling, 1962). 그 러나 세포막물질의 량이 건물량으로 따져 $60 \%$ 이하인 경우는 세포막 물질이 사료섭취량에 큰 영향을 미치지 않으나 세포막 물질이 $60 \%$ 이 상인 경우에는 사료의 섭취량을 떨어뜨린다고 하였다(Van Soest와 Marcus(1964). 고간류의 건 물섭취량은 대체로 저조하며 세포막 구성성분 이 건물당 $50 \%$ 이상으로 증가하면 사료섭취량 이 저하된다(Van Soest, 1965b)고 하였다.

Robles 등(1981)도 건물섭취량은 사료중에 세 포벽 물질이 건물로 $60 \%$ 나 그 이상이 되면 제 한을 받고 반추동물이 섭취하는 fiber의 량은 구조 탄수화물의 비율에 따라 다른데 세포벽 물질이 많고 lignin은 적게 들어있는 화본과는 두과에 비하여 섭취량이 제한을 받는다고 하였 다. 이와같이 저질 조사료의 섭취량이 감소하 는 것은 소화율이 낮고 반추위내 체류시간이 길기 때문(Campling 등, 1961)이라고 하였다.

조사료의 섭취량은 소화물질의 소화관내 정 체시간과 통과속도에 주로 영향을 받고, 사료 중의 에너지농도, 물리적 형태, 단백질 및 조섬 유 함량 등에 의하여도 영향을 받는다(Lusby와 Brent, 1976; Bae와 Welch, 1979)고 하였다.

그러나 조사료는 급여수준에 따라서 비육우 에게 미치는 효과가 상이한데, 급여수준이 높 을 경우에는 $\mathrm{NDF}$ 함량 및 입자도에 의하여 조 사료의 가치가 결정되어 사료섭취량을 조절하 는 물리적 요인으로 작용하지만(Sudweeks 등, 1981; Santini 등, 1983; Mertens, 1986), 급여수 준이 낮을 경우에는 생리 화학적 기작에 의하 여 사료섭취량이 조절되며 조사료는 반추위의 기능을 유지시켜 소화 장애를 최소화하는 작용 을 한다(Bartley, 1976; Mertens, 1986)고 하였다.

Mader와 Horn(1986)은 비육우 방목 시 밀짚 이나 수단 건초 같은 저질 조사료를 일일 두당 $0.91 \sim 1.36 \mathrm{~kg}$ 정도 급여하면 일당 증체량은 감 소하나, 저질 조사료를 급여하면 장내 통과속 도가 지연되어 조사료의 이용이 증가되고 고창 증의 발생도 감소된다고 하였다.

총사료섭취량은 비육초기에는 $\quad 9.91 \sim 9.93 \mathrm{~kg}$ 이었고, 비육중기에는 $10.88 \sim 11.23 \mathrm{~kg}$ 이었으며, 
비육후기에는 $10.98 \sim 11.29 \mathrm{~kg}$ 으로서 조사료로 서 대나무 급여수준간에 총사료섭취량에서 큰 차이가 없었고 비육전기간에 걸친 전체 평균 총사료섭취량은 볏짚 급여구와 대나무 $30 \%$ 급 여구는 $10.64 \mathrm{~kg}$, 대나무 $40 \%$ 급여구는 $10.78 \mathrm{~kg}$ 및 대나무 $50 \%$ 급여구는 $10.81 \mathrm{~kg}$ 으로서 처리 구간에 사료섭취량에 큰 차이가 없었다.

Baile와 McLaughlin(1987)은 섭취하는 사료의 물리적 형태가 여러 가지 사양조건하에서 사료 섭취량을 조절하는 주 요인은 아니라고 하였으 나 본 시험에서는 대나무 급여구가 암모니아 처리 볏짚 급여구 보다 비육시기별로 조사료섭 취량이 약간씩 증가하여서 급여하는 조사료의 질이 떨어지면 조사료의 섭취량은 증가하는 것 으로 사료된다. 진 등(2001)은 젖소 거세우의
일당사료섭취량은 비육 전기간에 건물로 8.88 $\sim 9.86 \mathrm{~kg}$ 이라고 하여서 본 시험의 $10.64 \sim 10.81$ $\mathrm{kg}$ 보다 약간 낮았다.

사료효율은 비육초기에는 8.86 9.62이었고, 비육중기에는 $12.23 \sim 16.04$ 이었으며, 비육후기 에는 15.46 19.47로서 일반적으로 대나무의 급 여수준이 증가할수록 사료효율은 나빠졌으나 대나무 30\% 급여구는 암모니아 처리 볏짚 급 여구와는 차이가 없었고, 전 비육기간에서의 사료효율은 12.24 15.04였으나 대나무의 30\% 급여구는 암모니아 처리 볏짚 급여구와 사료효 율은 차이가 없었다. 그러므로 사료섭취량이나 사료효율면에서도 젓소 거세우에게 조사료원으 로 대나무 사료를 $30 \%$ 까지는 암모니아 처리 볏짚에 대신하여 급여할 수 있을 것 같다.

Table 6. Economical analysis for Hostein steers fed different levels of crushed bamboo chip containing stem plus leaves

\begin{tabular}{|c|c|c|c|c|c|c|c|c|}
\hline \multirow{2}{*}{ Item } & \multicolumn{2}{|c|}{$0 \%$} & \multicolumn{2}{|c|}{$30 \%$} & \multicolumn{2}{|c|}{$40 \%$} & \multicolumn{2}{|c|}{$50 \%$} \\
\hline & Intake $^{1)}$ & $\operatorname{Cost}^{2)}$ & Intake $^{1)}$ & $\operatorname{Cost}^{2)}$ & Intake $^{1)}$ & $\operatorname{Cost}^{2)}$ & Intake $^{1)}$ & $\mathrm{Cost}^{2)}$ \\
\hline \multicolumn{9}{|l|}{ "Concentrate } \\
\hline First fattening & 1,287 & 283.14 & 1,275 & 280.50 & 1,278 & 281.16 & 1,274 & 280.28 \\
\hline Mid fattening & 1,451 & 333.73 & 1,426 & 327.98 & 1,437 & 330.51 & 1,419 & 326.37 \\
\hline Finishing & 1,571 & 377.4 & 1,547 & 371.28 & 1,562 & 374.88 & 1,542 & 370.08 \\
\hline Total & 4,309 & 993.91 & 4,248 & 979.76 & 4,277 & 986.55 & 4,235 & 976.73 \\
\hline \multicolumn{9}{|l|}{ Roughage } \\
\hline First fattening & 1,490 & 178.80 & 1,485 & 151.47 & 1,488 & 142.85 & 1,487 & 133.83 \\
\hline Mid fattening & 1,741 & 208.92 & 1,765 & 180.03 & 1,784 & 171.26 & 1,797 & 161.73 \\
\hline Finishing & 1,892 & 227.04 & 1,867 & 190.43 & 1,916 & 183.94 & 1,919 & 172.71 \\
\hline Total & 5,123 & 614.76 & 5,117 & 521.93 & 5,188 & 498.05 & 5,203 & 468.27 \\
\hline Total feed cost (won) & \multicolumn{2}{|c|}{$1,608.67$} & \multicolumn{2}{|c|}{$1,501.69$} & \multicolumn{2}{|c|}{$1,484.60$} & \multicolumn{2}{|c|}{$1,445.00$} \\
\hline Feed cost/kg gain ${ }^{3)}$ & \multicolumn{2}{|c|}{3,748} & \multicolumn{2}{|c|}{3,582} & \multicolumn{2}{|c|}{3,824} & \multicolumn{2}{|c|}{3,972} \\
\hline Calf price (won) & \multicolumn{2}{|c|}{$1,000.00$} & \multicolumn{2}{|c|}{$1,000.00$} & \multicolumn{2}{|c|}{$1,000.00$} & \multicolumn{2}{|c|}{$1,000.00$} \\
\hline Body weight (kg) & \multicolumn{2}{|c|}{728.9} & \multicolumn{2}{|c|}{720.5} & \multicolumn{2}{|c|}{690.4} & \multicolumn{2}{|c|}{670} \\
\hline Carcass weight (kg) & \multicolumn{2}{|c|}{401.5} & \multicolumn{2}{|c|}{418.6} & \multicolumn{2}{|c|}{381.1} & \multicolumn{2}{|c|}{376.5} \\
\hline Unit price (won/kg) & \multicolumn{2}{|c|}{7,099} & \multicolumn{2}{|c|}{6,871} & \multicolumn{2}{|c|}{6,895} & \multicolumn{2}{|c|}{6,799} \\
\hline Meat price (won) & \multicolumn{2}{|c|}{$2,850.25$} & \multicolumn{2}{|c|}{$2,876.20$} & \multicolumn{2}{|c|}{$2,627.68$} & 2,5 & 9.82 \\
\hline by-products (won) & & 0.78 & & 1.91 & & 3.98 & & 7.77 \\
\hline Income (won) & & 2.35 & & 0.69 & & 7.06 & & 2.59 \\
\hline Index & & & & 2.6 & & 2.4 & & 6.1 \\
\hline
\end{tabular}

1) Unit : kg. ${ }^{2)}$ Uni t: 1000 won. 
그런데 비육후기 사료에 조사료를 많이 급여 하고 농후사료를 줄이는 문제는 가축의 생산성 및 육질과 관련이 있다고 하였다(Bowling 등, 1978).

본 시험에 사용된 대나무의 건물은 $63.22 \%$, 조섬유는 $29.50 \%$, 조단백질은 $3.06 \%$ 및 $\mathrm{ADF}$ 는 $36.84 \%$ 였고 무기물중에서는 $\mathrm{K}(3942 \mathrm{ppm})$, $\mathrm{Ca}(1196 \mathrm{ppm})$ 및 $\mathrm{P}(1146 \mathrm{ppm})$ 순으로 높았는데 (Table 2, 3), 박과 류(1996)도 대나무의 무기물 함량은 $\mathrm{Ca}, \mathrm{Mg}$ 및 $\mathrm{P}$ 순으로 많았다고 하였다.

젓소 거세우 비육시 조사료원으로서 대나무 (잎과 줄기 포함) 급여가 경제성에 미치는 영향 을 보면 Table 6에 나타난 바와같이 농후사료 비는 두당 976 993천 원으로서 처리구간에 큰 차이가 없었으나, 조사료비는 두당 468 614 천 원으로 대나무의 급여수준이 증가할수록 점 차적으로 감소하였다. 사료단가는 비육초기는 $\mathrm{kg}$ 당 220원, 비육중기는 230원 비육후기는 240 원으로 환산하였고, 볏짚은 $\mathrm{kg}$ 당 120 원으로 계산하였으며, 대나무는 잎과 줄기를 모두 파 쇄하여 $\mathrm{kg}$ 당 60 원으로 계산하였다. 도체단가는 볏짚 급여구는 $\mathrm{kg}$ 당 7,099 원으로 대나무 30\% 區의 6,871원이나 $40 \%$ 급여구의 6,895원 보다 는 약간 높았고 $50 \%$ 급여구의 6,799 원 보다는 4.4\% 높았다. 조수익에서는 대나무 30\% 급여구 가 볏짚 급여구에 비하여 $12.6 \%$ 높았고, 볏짚 급여구는 대나무 $40 \%$ 급여구 보다는 $17.6 \%$ 높 았고, 대나무 50\% 급여구에 비하여 $23.9 \%$ 가 높
았다. $\mathrm{kg}$ 증체에 소요되는 사료비도 조수익의 순서와 일치하였다. 그러므로 본 시험결과에 의하면 젖소 거세우 비육시 조사료중에 대나무 를 볏짚에 대하여 $30 \%$ 정도 대체하여 급여하 는 것이 수익면에서 유리하다고 사료된다.

Brennan 등(1987)은 거세우에게 full corn silage 사료나 농후사료를 다급하면서 조사료는 최소 한으로 급여하는 것이 경제적으로 가장 좋았다 고 하였다. 진 등(2001)은 젓소 거세우에게 비 육기간동안 목건초에 발효사료를 함께 급여하 였을 때 목건초만 급여한 구보다 소득이 더 높 았다고 하였다.

\section{2. 면양을 이용한 소화시험}

조사료로서 암모니아 처리 볏짚을 급여하면 서 대나무의 급여수준을 달리하여 면양에게 급여하였을 때 소화율에 미치는 영향을 보면 Table 7에 제시된 바와 같이 건물소화율은 조 사료로서 암모니아 처리 볏짚만 급여한 구가 $70.6 \%$ 로서 제일 높았으나 암모니아 처리 볏 짚을 급여하면서 대나무 $30 \%$ 를 대체 급여구 (69.8\%)와는 차이가 없었고 대나무 급여수준간 에는 대나무 급여수준이 높아질수록 건물의 소 화율은 점차적으로 감소하였다 $(\mathrm{p}<0.05)$. 조지방 소화율도 건물소화율과 같이 대나무의 급여수 준이 증가할수록 점차적으로 감소하였으나 볏 짚 급여구(89.4\%)와 대나무 30\% 급여구(88.8\%)

Table 7. Effects of the substitution levels of crushed bamboo chip for ammoniated rice straw on digestibility of sheep

\begin{tabular}{rcccccc}
\hline \multirow{2}{*}{$\begin{array}{c}\text { Treat } \\
\text { ment }\end{array}$} & \multicolumn{5}{c}{ Digestibility(\%) } \\
\cline { 2 - 6 } & DM & Fat & Protein & Crude fiber & NFE & Ash \\
\hline \hline $0 \%$ & $70.57 \pm 1.21^{\mathrm{a}}$ & $89.37 \pm 0.70^{\mathrm{a}}$ & $67.41 \pm 2.11^{\mathrm{a}}$ & $59.53 \pm 1.59^{\mathrm{a}}$ & $75.21 \pm 1.82^{\mathrm{b}}$ & $41.73 \pm 1.08^{\mathrm{b}}$ \\
$30 \%$ & $69.75 \pm 2.05^{\mathrm{ab}}$ & $88.83 \pm 0.87^{\mathrm{a}}$ & $69.95 \pm 2.76^{\mathrm{a}}$ & $40.21 \pm 5.73^{\mathrm{b}}$ & $78.63 \pm 1.24^{\mathrm{a}}$ & $44.14 \pm 1.85^{\mathrm{a}}$ \\
$40 \%$ & $67.49 \pm 0.58^{\mathrm{bc}}$ & $81.85 \pm 0.47^{\mathrm{b}}$ & $70.23 \pm 0.76^{\mathrm{a}}$ & $41.64 \pm 2.61^{\mathrm{b}}$ & $77.38 \pm 0.47^{\mathrm{ab}}$ & $31.45 \pm 0.58^{\mathrm{c}}$ \\
$50 \%$ & $66.60 \pm 0.82^{\mathrm{c}}$ & $81.85 \pm 1.62^{\mathrm{b}}$ & $70.69 \pm 0.60^{\mathrm{a}}$ & $36.44 \pm 2.65^{\mathrm{b}}$ & $76.77 \pm 0.52^{\mathrm{ab}}$ & $29.73 \pm 0.56^{\mathrm{c}}$ \\
\hline
\end{tabular}

Means \pm SD

Means with different superscripts are significantly different $(\mathrm{P}<0.05)$.

$0 \%$ : ammoniated rice straw 100\%; 30\%: bamboo chip with leaves plus

stem 30\%; 40\%: bamboo chip with leaves plus stem $40 \%$;

50\%: bamboo chip with leaves plus stem 50\%. 
간에는 조지방소화율에 차이가 없었고 대나무 $40 \%(81.9 \%)$ 와 $50 \%$ 급여구(81.9\%)간에도 차이가 없었다. 그러나 조단백질 소화율은 암모니아 처리 볏짚 급여구와 대나무 급여수준을 달리한 처리구간에 차이가 없었다. 조섬유 소화율은 조사료로서 암모니아 처리 볏짚만 급여한 구가 $59.5 \%$ 로 제일 높았고 대나무 급여수준간에는 차이가 없었다. 이는 Table 2에 제시된 바와 같 이 대나무중에는 암모니아 처리 볏짚에 비하여 조섬유, $\mathrm{NDF}$ 및 $\mathrm{ADF}$ 함량이 높은데 기인하는 것 같다. NFE의 소화율은 대나무 $30 \%$ 급여구 가 제일 높았으나 대나무 급여구간에는 차이가 없었고, 암모니아 볏짚 급여구는 대나무 급여 구보다 낮았다 $(\mathrm{p}<0.05)$. 조회분 소화율은 대나 무 $30 \%$ 급여구(44.1\%)가 제일 높았고 다음은 볏짚(41.7\%) 급여구였으며, 대나무 $40 \%$ 와 $50 \%$ 급여구간에는 차이가 없었다. 그러므로 소화율 면에서는 대나무를 암모니아 처리 볏짚에 대하 여 $30 \%$ 까지는 대체하여 급여하여도 좋을 것 같다.

그러나 사료의 소화율은 암모니아 처리 볏짚 에 대한 대나무의 대체 급여수준이 $40 \%$ 이상 에서는 감소하였는데 이는 대나무중에 들어있 는 $\mathrm{ADF}$ 및 lignin 함량과 관련이 있을 것 같다. 왜냐하면 lignin은 소화과정 중에 일부 분해되 기도 하지만 조사료의 소화율에 나쁘게 영향을 미친다고 하였다(Fahey 등, 1980).

또한 사료의 소화율은 여러 가지 요인들 중 에서 일반성분에 의하여도 영향을 받는데 조섬 유와 NFE로는 소화기내의 효소에 의하여 소화 되는 탄수화물과 미생물이 분비하는 효소에 의 하여 소화되는 탄수화물을 구분하기가 쉽지 않 은데 그 이유는 hemicellulose와 lignin 중의 일 부는 NFE에 포함되어 있기 때문이라고 하였다 (Fonnesbeck 등, 1981).

또한 사료의 소화율은 사료중의 lignin 함량 에 의해서 크게 영향을 받는데 lignin 함량이 총 고형물의 $5 \%$ 정도인 목건초의 cellulose는 약 $80 \%$ 가 소화되지만 lignin 함량이 $10 \%$ 인 비 교적 성숙한 목초의 cellulose 소화율은 $60 \%$ 에 도 미치지 못한다고 하였다. 그러므로 반추위 내에서의 cellulose의 소화율은 식물체가 얼마나
목질화 되었느냐에 달려있는 것 같은데 lignin과 hemicellulose 소화율 및 lignin과 가소화유기물과 의 관계는 각각 -0.83 및 -0.84 라고(Lippke, 1980) 하였다.

김 등(1987)도 건물소화율은 대맥 호숙기 사 일리지구가 가장 높았고 대맥 황숙기 사일리지 구가 가장 낮았다고 하였다. 그래서 반추가축 의 능력은 조사료의 질과 관련이 깊다고 하였 다. 강 등(1998)은 재래산양에서 건물, 에너지, 조단백질 및 섬유소 소화율은 알팔파 급여구가 아카시아나무 파쇄물 50\% 및 $100 \%$ 급여구보다 높게 나타났다고 하였다. 염소에게 oat 나뭇가 지를 급여하였을 때 건물소화율은 $46.7 \%$ 라고 하였고(Natis와 Malechek, 1981), 소가 장 내용물 이 가득 차도록 사료를 섭취하면 사료의 소화율 은 감소한다고 하였다(Montgomery와 Baumgardt, 1965).

그런데 사료의 소화율은 반추위내에서 사료 의 retention time과 밀접한 관련이 있고 동물의 품종보다는 섭취하는 사료와 더 관련이 있다고 (Huston 등, 1986) 하였다. 그러나 Adewaken 등 (1989)은 사일리지 종류간에는 건물소화율에 차 이가 없었지만 fescue 건초를 섭취한 소가 건물 소화율이 제일 낮았다고 하였다. Ledoux 등 (1985)도 건물과 전분의 소화율은 fescue 건초 의 수준이 증가할수록 직선적으로 감소한다고 하였고 다만 $\mathrm{ADF}$ 소화율은 직선적으로 증가한 다고 하였다.

\section{3. 도체시험}

젖소 거세우에게 조사료원으로 암모니아 처 리 볏짚과 대나무를 급여하였을 때 육량과 육 질등급에 미치는 영향을 보면 Table 8에 제시 된 바와 같이 도체율은 조사료원으로 대나무 $30 \%$ 급여구가 도체율이 $58.1 \%$ 로 암모니아 처 리 볏짚 급여구보다 약간 높았고, 암모니아 처 리 볏짚 급여구와 대나무 $40 \%$ 구와 $50 \%$ 구간에 는 차이가 없었다. 등지방두께는 대나무 $30 \%$ 급여구가 $6 \mathrm{~mm}$ 로 암모니아 처리 볏짚 급여구 의 $4.7 \mathrm{~mm}$ 보다는 약간 두꺼웠으나 대나무 $40 \%$ 와 $50 \%$ 구는 암모니아 처리 볏짚 급여구에 
Table 8. Effect of the substitution levels of crushed bamboo chip for ammoniated rice straw on carcass characteristics of Holstein steers

\begin{tabular}{|c|c|c|c|c|}
\hline Item & $0 \%$ & $30 \%$ & $40 \%$ & $50 \%$ \\
\hline Body weight (kg) & $729.7^{\mathrm{a}} \pm 41.1$ & $720.5^{\mathrm{a}} \pm 40.3$ & $690.4^{\mathrm{b}} \pm 35.8$ & $670.0^{\mathrm{b}} \pm 35.4$ \\
\hline Carcass weight (kg) & $401.5^{\mathrm{a}} \pm 6.5$ & $418.6^{\mathrm{a}} \pm 5.0$ & $381.1^{\mathrm{b}} \pm 5.5$ & $376.5^{\mathrm{b}} \pm 4.7$ \\
\hline Dressing percentage (\%) & $55.9 \pm 0.56$ & $58.1 \pm 0.73$ & $55.2 \pm 1.00$ & $56.5 \pm 0.75$ \\
\hline \multicolumn{5}{|l|}{ Beef yield } \\
\hline Backfat thickness (mm) & $4.7 \pm 0.67$ & $6.0 \pm 1.67$ & $5.0 \pm 2.0$ & $5.5 \pm 0.75$ \\
\hline Eye muscle area $\left(\mathrm{cm}^{2}\right)$ & $80.0^{\mathrm{a}} \pm 1.83$ & $75.0^{\mathrm{b}} \pm 2.55$ & $69.5^{c} \pm 3.50$ & $68.3^{c} \pm 5.67$ \\
\hline Yield index & $67.91 \pm 0.24$ & $66.97 \pm 0.18$ & $66.92 \pm 0.47$ & $66.03 \pm 0.15$ \\
\hline Yield grade $^{1)}$ & B & B & B & B \\
\hline \multicolumn{5}{|l|}{ Beef quality } \\
\hline Beef color $^{2)}$ & $4.3 \pm 0.17$ & $4.3 \pm 0.33$ & $4.0 \pm 0.10$ & $5.3 \pm 0.33$ \\
\hline Fat color $^{3)}$ & $2.0 \pm 0.10$ & $2.3 \pm 0.33$ & $2.0 \pm 0.10$ & $2.3 \pm 0.33$ \\
\hline Texture $^{4)}$ & $2.0 \pm 0.10$ & $2.0 \pm 0.10$ & $2.0 \pm 0.10$ & $2.0 \pm 0.10$ \\
\hline Maturity $^{5)}$ & $2.0 \pm 0.10$ & $2.0 \pm 0.10$ & $2.0 \pm 0.10$ & $2.0 \pm 0.10$ \\
\hline Marbling score ${ }^{6)}$ & $1.5 \pm 0.17$ & $1.3 \pm 0.33$ & $2.0 \pm 0.33$ & $1.0 \pm 0.10$ \\
\hline Quality grade ${ }^{7)}$ & $2.7^{\mathrm{a}} \pm 0.17$ & $2.3^{\mathrm{a}} \pm 0.33$ & $2.5^{\mathrm{a}} \pm 0.33$ & $2.3^{\mathrm{a}} \pm 0.33$ \\
\hline
\end{tabular}

Means \pm SD

0\%: ammoniated rice straw 100\%; 30\%: bamboo chip with leaves plus stem 30\%; 40\%: bamboo chip with leaves plus stem 40\%; 50\%: bamboo chip with leaves plus stem 50\%.

$\mathrm{a,b}, \mathrm{c}$ Means with same superscript are not significantly different $(\mathrm{p}<0.05)$.

1) $\mathrm{A}=$ Better than average, $\mathrm{B}=$ average, $\mathrm{C}=$ lower than average.

2) 1 = light red, 7 = dark red.

3) 1 = white, 7 = yellow.

4), 5) 1 = low numbers for better quality.

6) 7 = high numbers for better quality.

7) $1+$ = best, 1 = better, 2 = average, 3 = lower.

비교하여 큰 차이는 없었다. 배 최장근 단면적 은 암모니아 볏짚 급여구가 $80 \mathrm{~cm}^{2}$ 로 대나무 $30 \%, 40 \%$ 및 $50 \%$ 급여구에 비하여 제일 넓었 고, 대나무 급여수준 간에는 대나무 급여수준 이 높아질수록 배 최장근 단면적이 점차적으로 좁아졌다. 그러나 육량지수는 암모니아 처리 볏짚 급여구와 대나무 30\%, 40\% 및 50\% 급여 구간에 큰 차이가 없었고 육량 등급은 처리구 모두 $\mathrm{B}$ 등급을 받아서 처리구간에 차이가 없었 다.

육질등급에서 근내지방도는 1.0 2.0으로 암
모니아 처리 볏짚 급여구와 대나무 급여구간에 유의적인 차이는 없었다. 육색은 암모니아 처 리 볏짚 급여구와 대나무 $30 \%$ 및 $40 \%$ 급여구 간에는 4.3 정도로 처리구간에 차이가 없었으 나 대나무 50\% 급여구는 5.3으로 약간 높았다. 지방색은 처리구간에 $2.0 \sim 2.3$ 으로 비슷하였고, 조직감도 처리구간에 2.0 으로 같았고, 성숙도도 처리간에 2.0으로 동일하였으며, 육질등급은 처 리구간에 전체적으로는 B2 등급이었으나 암모 니아 처리 볏짚 급여구가 B2.7로 대나무 30\% 와 $40 \%$ 급여구의 B2.3 내지 B2.5 및 대나무 
$50 \%$ 급여구의 B2.3 보다 약간 낮았고 대나무 급여구간에는 2.3 2.5로 비슷하였다.

그러므로 젓소 수소도 거세를 실시하여 사료 를 거세우의 사료급여체계에 맞게 급여하면서 $700 \mathrm{~kg}$ 정도로 장기간 비육을 실시하면 육질등 급이 현행의 3 등급(97.4\%; 축산물등급판정소, 2003)에서 2 등급으로 향상될 수 있으며 이 때 에 조사료원을 개발하여 자가 급여 할 수 있다 면 사료비 절감면에서도 유리하리라 사료된다. 그러므로 본 시험 결과에 의하면 젖소 거세우 에게 대나무를 암모니아 처리 볏짚에 대하여 $30 \%$ 까지는 급여하여도 도체의 육량과 육질 등급에 영향을 미치지 않는 것으로 사료된다.

Jacobs 등(1977a, 1977b)은 거세우가 수소보다 육질등급이 더 높다고 하였고, 진 등(2001)은 젖소 거세우를 24 개월간 비육시 도체율은 51.5 $\sim 52.6 \%$ 이고 배 최장근 단면적은 $70.6 \sim 73.7 \mathrm{~cm}^{2}$ 라고 하여 본 연구의 결과보다 약간 낮고, 근 내지방도는 1.5 2.3, 육색은 4.4 5.1, 지방색은 2.8 4.1 및 육질등급은 2.3 2.7이라고 하여서 본 연구의 결과와 비슷하였다. 그런데 도체의 육량등급과 육질등급은 가축의 나이, 성별 및 출하시 체중과 관련이 있다(Danner 등, 1980)고 하였다.

비육우 사육시에 농후사료는 적게 급여하고 조사료는 많이 급여하여야 하는데 그러나 조사 료를 다급하면 도체율이 떨어지고, 냉장시 쇠 고기 수축율이 증가하고, 육질은 낮아지기 때 문에(Schroeder 등, 1980) 비육말기에 조사료 다 급에 대하여 논란이 있다. 木村 등(1996)도 비 육후기에 사료중의 조사료수준은 和牛의 도체 등급과 육질에 영향을 미칠 수 있다고 하였다. 국과 김(2002)은 한우 수소에게 무화과 발효물 을 $10 \%$ 첨가하여 급여하였을 때 근내지방도가 유의적으로 증가한다고 하였다.

또한 쇠고기의 기호성에 대한 조사료의 영향 에 대하여도 논란이 있는데 어떤 사람들은 조 사료 다급 쇠고기가 맛이 있다고 하였으나 (Oltjen 등, 1971; Cross와 Dinius, 1978), 또 어떤 사람들은 조사료 다급 쇠고기가 곡류 다급 쇠 고기보다 맛이 없다(Smith 등, 1977; Bowling 등, 1978; Brown 등, 1979, Hedrick 등, 1983)고
하였다.

IV. 요 약

젖소 거세우의 육질을 개선시키기 위하여 조 사료원으로서 대나무(잎과 가지포함)를 암모니 아 처리 볏짚 급여수준에 대하여 4 수준 $(0,30$, $40,50 \%)$ 으로 나누어 체중 $300 \mathrm{~kg}$ 부터 $700 \mathrm{~kg}$ 까지 급여하면서, 증체량, 사료섭취량, 사료효 율, 경제성, 소화율 및 도체특성에 미치는 영 향을 조사하여 다음과 같은 결과를 얻었다.

일당증체량은 대나무 $30 \%$ 급여수준은 암모 니아 볏짚 급여구와 차이가 없었으나 대나무 $40 \%$ 와 $50 \%$ 급여구는 일당증체량이 감소하였 다. 농후사료섭취량은 조사료중의 대나무 급여 수준에 의하여 처리구간에 큰 차이가 없었다. 조사료 섭취량은 대나무 급여수준이 높아질수 록 약간씩 증가하는 경향이었다. 총 사료섭취 량은 대나무 급여수준 간에 차이가 없었다. 사 료효율은 대나무 $30 \%$ 급여수준은 암모니아 처 리 볏짚 급여구와 차이가 없었으나 대나무 $40 \%$ 및 $50 \%$ 수준에서는 나빠졌다.

경제성에 미치는 영향을 보면 조수익에서는 대나무 $30 \%$ 급여구가 암모나아 볏짚 급여구에 비하여 약 $13 \%$ 높았으나, 대나무 $40 \%$ 와 $50 \%$ 급여구는 조수익이 낮았다.

건물, 조지방, 조단백질, 가용무질소물 및 조 회분 소화율은 대나무 $30 \%$ 급여구와 암모니아 처리 볏짚 급여구간에 차이가 없었으나, 조섬 유 소화율은 암모니아 처리 볏짚 급여구가 대 나무 급여구 보다 높았고, 대나무 급여수준 간 에는 차이가 없었다.

도체율과 등지방두께는 처리구간에 차이가 없었으나 배 최장근 단면적은 대나무의 급여수 준이 증가할수록 점차적으로 좁혀졌다. 육량등 급은 처리구간에 같은 $\mathrm{B}$ 등급이었다. 육색, 지 방색, 조직감, 성숙도 및 근내지방도도 처리구 간에 차이가 없었고, 육질등급은 처리구간에 2 등급이었다.

그러므로 본 연구에 의하면 젖소 수소는 거 세를 시키고 조사료로서 암모니아 볏짚을 급여 하면서 대나무(잎과 줄기포함)를 파쇄하여 $30 \%$ 
정도 대체 급여하면 젖소 거세우의 소득 향상 을 위해 바람직하다고 사료된다.

$$
\mathrm{V} \text {. 사 사 }
$$

본 연구는 2002년 농림부 농림기술관리센터 의 지원(관리번호:20010591)에 의하여 수행되었 음.

\section{VI. 인 용 문 헌}

1. Adewakun, L. O., Famuyiwa, A. O., Felix, A. and Omole, T. A. 1989. Growth performance, feed intake and nutrient digestibility by beef calves fed sweet sorghum silage, corn silage and fescue hay. J. Anim. Sci. 67:1341-1349.

2. Bae, D. H. and Welch, J. G. 1979. Study on the nutritive value of the Miscanthus sinensis in relation to its maturity. Korean J. Anim. Sci. 21:503-508.

3. Balch, C. C. and Campling, R. C. 1962. Regulation of voluntary intake in ruminants. Nutr. Abstr. Rev. 32:669.

4. Baile, C. A. and McLaughlin, C. L. 1987. Mechanisms controlling feed intake in ruminants:a review. J. Anim. Sci. 64:915-922.

5. Bartley, E. E. 1976. Bovine Saliva: production and functions. In: M. S. Weinberg and Metabolism. p 61. Church and Dwight Co., New York.

6. Bowling, R. A., Riggs, J. K., Smith, G. C., Carpenter, Z. L., Reddish, R. L. and Butler, O. D. 1978. Production, carcass and palatability characteristics of steers produced by different management systems. J. Anim. Sci. 46(2):333-340.

7. Brennan, R. W., Hoffman, M. P., Parrish, F. C., Epplin, F., Bhide, S. and Heady, E. O. 1987. Effect of differing ratios of corn silage and corn grain on feedlot performance, carcass characteristics and projected economic returns. J. Anim. Sci. 64(1):23-31.

8. Brown, H. J., Melton, S. L., Reiman, M. J. and
Backus, W. R. 1979. Effects of energy intake and feed source on chemical changes and flavor of ground beef during frozen storage. J. Anim. Sci. 48:338-347.

9. Campling, R. C., Freer, M. and Balch, C. C. 1961. Factors affecting the voluntary intake of food by cows. 2. The relationship between the voluntary intake of roughages, the amount of digesta in the reticulo-rumen and the rate of disappearance of digesta from the alimentary tract. Brit. J. Nutr. 15:531-540.

10. Cross, H. R. and Dinius, D. A. 1978. Carcass and palatability characteristics of beef steers finished on forage diets. J. Anim. Sci. 47:12651271.

11. Danner, M. L., Fox, D. G. and Black, J. R. 1980. Effect of feeding system on performance and carcass characteristics of yearling steers, steer calves and heifer calves. J. Anim. Sci. 50(3):394404.

12. Fahey, G. C., Jr., Al-Haydari, S. Y., Hinds, F. C. and Short, D. E. 1980. Phenolic compounds in roughages and their fate in the digestive system of sheep. J. Anim. Sci. 50(6):1165-1172.

13. Fonnesbeck, P. V., Christiansen, J. L. and Harris, L. E. 1981. Factors affecting digestibility of nutrients by sheep. J. Anim. Sci. 52(2):363-376.

14. Gill, D. R., Owens, F. N., Fent, R. W. and Fulton, R. K. 1979. Thiopeptin and roughage level for feedlot steers. J. Anim. Sci. 49(5):1145-1150.

15. Hedrick, H. B., Paterson, J. A., Matches, A. G., Thomas, J. D., Morrow, R. E. Stringer, W. C. and Lipsey, R. J. 1983. Carcass and palatability characteristics of beef produced on pasture, corn silage and corn grain. J. Anim. Sci. 57(4): 791-801.

16. Huston, J. E., Rector, B. S., Ellis, W. C. and Allen, M. L. 1986. Dynamics of digestion in cattle, sheep, goats and deer. J. Anim. Sci. 62(1):208-215.

17. Jacobs, J. A., Hurst, C. E., Miller, J. C., Howes, A. D., Gregory, T. L. and Ringkob, T. P. 1977a. 
Bulls versus steers. I . Carcass composition, wholesale yields and retail values. J. Anim. Sci. 45(4):695698.

18. Jacobs, J. A., Miller, J. C., Sauter, E. A., Howes, A. D., Araji, A. A., Gregory, T. L. and Hurst, C. E. 1977b. Bulls versus steers. П. Palatability and retail acceptance. J. Anim. Sci. 45(4):699-702.

19. Ledoux, D. R., Williams, J. E., Stroud, T. E., Garner, G. B. and Paterson, J. A. 1985. Influence fo forage level on passage rate digestibility and performance cattle. J. Anim. Sci. 61(6):1559-1566.

20. Lippke, H. 1980. Forage characteristics related to intake, digestibility and gain by ruminants. J. Anim. Sci. 50(5):952-961.

21. Lusby, K. S. and Brent, B. E. 1976. An experimental model for Polio Encephalomalacia. J. Anim. Sci. 35:270(Abstract).

22. Mader, T. L. and Horn, G. W. 1986. Low-quality roughages for steers grazing wheat pasture. $\square$. Effect of wheat forage intake and utilization. J. Anim. Sci. 62(4):1113-1119.

23. Mertens, D. R. 1986. Effect of physical characteristics, forage particle size and density on forage utilization. Proc. Afla Nutr. Symp. p. 91. St. Louis, Mo.

24. Montgomery, M. J. and Baumgardt, B. R. 1965. Regulation of food intake in ruminants. I. Pelleted rations varying in energy concentration. J. Dairy Sci. 48:569-574.

25. Nastis, A. S. and Malechek, J. C. 1981. Digestion and utilization of nutrients in oak browse by goats. J. Anim. Sci. 53(2):283-290.

26. Oltjen, R. R., Rumsey, T. S. and Putnam, P. A. 1971. All forage diets for finishing beef cattle. J. Anim. Sci. 32:327-333.

27. Riquelme, E., Dyer, I. A., Baribo, L. E. and Couch, B. Y. 1975. Wood cellulose as an energy source in lamb fattening rations. J. Anim. Sci. 40(5)977-981.

28. Robles, A. Y., Belyea, R. L., Martz, F. A., Weiss, M. F. and Maus, R. W. 1981. intake, digestibility, ruminal characteristics and rate of passage of orchardgrass dites fed to sheep. J. Anim. Sci. 53(2):489-493.

29. Santini, F. J., Hardie, A. R., Jorgensen, N. A. and Finner, M. F. 1983. Proposed use of asjusted intake based on forage particle length for calculations of roughage indexe. J. Dairy Sci. 66:811-820.

30. Schroeder, J. W., Cramer, D. A., Bowling, R. A. and Cook, C. W. 1980. Palatability, shelflife and chemical differences between forage-and grainfinished beef. J. Anim. Sci. 50:852-859.

31. Smith, G. M., Crouse, J. D., Mandigo, R. W. and Neer, K. L. 1977. Influence of feeding regime and biological type on growth, composition and palatability of steers. J. Anim. Sci. 45:236-253.

32. Sudweeks, E. M., Ely, L. O., Mertens, D. R. and Sisk, L. R. 1981. Assessing maximum amounts and form of roughages in ruminant diets: Roughage value index system. J. Anim. Sci. 53 (5):1406-1411.

33. Van Soest, P. J. and Marcus, W. C. 1964. Method for the determination of cell wall constituents in forages using detergent and the relationship between this fraction and voluntary intake and digestibility. J. Dairy Sci. 47:704.

34. Van Soest, P. J. 1965a. Symposium on factors influencing the voluntary intake of herbage by ruminants: Voluntary intake in relation to chemical composition and digestibility. J. Anim. Sci. 23: 834-844.

35. Van Soest, P. J. 1965b. Comparison of two different equations for prediction of digestibility from cell content, cell wall constituents, and lignin content of acid detergent fiber. J. Dairy Sci. 48:815.

36. 강병호, 박덕섭, 김건중, 김용익, 김용국. 1998. 육성초기 한국재래산양 사료로서 아까시아나무 파쇄물의 영양가치. 한축지 $40(2): 175-184$.

37. 국 길, 김광현. 2002. 무화과 발효물의 급여가 한 우의 생산성, 혈액성상 및 육질에 미치는 영향. 한국동물자원과학회지. 44(6):739-746. 
38. 김준식, 이현준, 김광종, 조윤연, 지설하, 하종규. 1987. 대맥사일리지 및 대맥펠렛 급여가 젖소의 유량, 유성분, 반추위내 발효에 미치는 영향. 한 국축산학회지. 29(11):514-522.

39. 농협중앙회. 2000. 젖소 수소비육 경제성 분석 검토. 한우낙농부.

40. 木村信熙, 木村聖二, 小迫孝實, 井村毅. 1996. 黑毛和種 去勢牛 肥育後期における 粗飼料給 與水準が 枝肉性狀 および 枝肉脂肪の 脂肪酸 組成に及ぼす 影響. 日畜會報, 67(6):554-560.

41. 박인협, 류석봉. 1996. 왕대속 대나무의 물질생산 및 무기영양물 분배에 관한 연구. 한국임학회지 85(3):453-461.

42. 산림청. 2000. 임업통계연보. 제 30 호.
43. 常石英作, 佐藤博, 渡辺彰. 1993. 肉用牛の肥育 前期における 高繊維質 粗飼料の 給與が 肥育 後期の 增體に及ぼす 影響. 日畜會報, 64(4):386394.

44. 정민국. 1999. 육우고기 전문판매장의 활성화 방 안. 낙농육우. 78-81.

45. 진신흠, 고문석, 오운용, 박남건, 이종언, 고서봉. 2001. 젖소 사육기술 개선 연구. 제주농협시험장.

Code : LS 0301:29-42.

46. 축산물등급판정소. 2003. 축산물등급판정연보. 47. 한국단미사료협회. 2005. 단미. 보조사료편람. (접수일자 : 2006. 4. 10. / 채택일자 : 2006. 5. 24.) 